\title{
Utilization of Landsat Data for Quantifying and Predicting Land Cover Change in the Bumbuna Watershed in Sierra Leone
}

\author{
Abubakarr Mansaray, Abdulai Barrie \\ Bumbuna Watershed Management Authority, Bumbuna, Sierra Leone \\ Email:absmansaray@gmail.com
}

How to cite this paper: Mansaray, A. and Barrie, A. (2016) Utilization of Landsat Data for Quantifying and Predicting Land Cover Change in the Bumbuna Watershed in Sierra Leone. Natural Resources, 7, 495-504. http://dx.doi.org/10.4236/nr.2016.79042

Received: August 10, 2016

Accepted: September 6, 2016

Published: September 9, 2016

Copyright $\odot 2016$ by authors and Scientific Research Publishing Inc. This work is licensed under the Creative Commons Attribution International License (CC BY 4.0).

http://creativecommons.org/licenses/by/4.0/ (c) (i) Open Access

\begin{abstract}
Rural communities in third world countries are concerned over land use changes resulting from resource exploitation. This is the case for the Bumbuna watershed in Sierra Leone following impoundment of the Bumbuna reservoir in 2009. Farmers have increased activities along the riparian zones in protest against inundation of their farmlands. The dam operators warn this practice would threaten sustainable power supply; the farmers contend the reservoir is increasing and taking over their farms. However, it is difficult to resolve this issue without a means of quantifying the change and developing early warning systems for land cover in the watershed. This research presents a case for the use of remotely sensed Landsat data for quantification of land cover change and the development of predictive models to inform preparedness for imminent problems that may arise from land use practices. In situ water loggers, in combination with manual readings, recorded water levels in 30-minute intervals since 2009. These datasets combined with spectral values of Landsat 7 and Landsat 8 for the development of regression algorithms for predictive purposes. Digital photographs and satellite imagery illustrated the changes in land cover over time (a 33\% water rise and 44\% NDVI change from 2009 to 2015). These visual and spectral pictures confirm the usefulness of remotely sensed data for early warning systems in the watershed. Results of the regression analysis show Band 1 (Blue) and Band 4 (NIR) as statistically significant predictors for water level in the reservoir. The tests accounted for $84 \%\left(\mathrm{R}^{2}\right)$ of the data with p-values less than $\alpha$ at the 0.05 confidence level. However, future trials of the model will consider reducing the 4.6 error margin to minimize deviations from the observed data.
\end{abstract}

\section{Keywords}

Watershed, Hydroelectric Power, Farming, Water Loggers, Landsat, Remote Sensing, Spectral Data 


\section{Introduction}

Rural communities in third world countries are becoming increasingly concerned over land use practices that may lead to major changes in land cover and pose threats to their chances of survival [1]. This is the case in the Bumbuna watershed in Sierra Leone. There are two main concerns over land cover change in the watershed [2]. Firstly, the Bumbuna Hydroelectric Project (BHP), the largest source of electricity supply to the nation's capital, is under accusation from local farmers and settlers for land degradation. The dam operators, on the other hand, worry about the frequency and magnitude of slash and burn farming as a threat to river flow in the area.

During the farming season, local farmers cultivate plots of forestland mainly for rice production. Traditionally, farmers would allow the farmland to fallow for a minimum of 7 years before coming back to that same plot. However, this fallow period has dramatically reduced to about every other year due to increase in other livelihood activities that also depend on the same piece of land. This farming concern became more obvious when the Government of Sierra Leone (GoSL) commissioned the Bumbuna power plant in 2009. The dam filled up and expanded into a reservoir taking over farmlands, communities, and some vegetation.

The stakeholders have been in a heated debate over the impact of these two activities. The dam operators warn that farming along the shoreline would change the fluvial geomorphology of the area and affect electricity generation. The farmers, on the other hand, contend that the water level keeps rising and shifting the riparian buffer inwards towards their farmland. Farming is an integral part of their tradition, in addition to being their major means of livelihood.

In anticipation of this controversy, the GoSL, in 2008, developed a policy to promote best management practices (BMPs) and alleviate environmental and social problems in the watershed [2]. This law ushered in the Bumbuna Watershed Management Authority (BWMA) to facilitate implementation of the BMPs. The BWAMA and development partners have worked with farmers to establish a 100 -m width riparian buffer to protect the stream banks and minimize sedimentation into the Bumbuna reservoir. However, keeping the riparian buffer intact has challenged the stakeholders over the years.

Meanwhile, no data exists to show the mechanisms of catchment change in the area, the impact on these activities, and to what magnitude they matter. Advances in the availability of remote sensing datasets and the understanding of their benefits and limitations provide the potential to assist in overcoming this challenge [3]. Combining these datasets with ground truth data and an understanding of the underlying mechanisms is an active area of scientific research that could address such unexplored area.

The underlying principles behind satellite remote sensing for natural resource research include but are not limited to electromagnetic radiation, image acquisition and processing, and field data gathering [4]. Data from electromagnetic radiation combines with environmental data to simulate trends and processes. The simulation happens through computer software packages that synthesize information into useful formats for algorithm development. The computer algorithms deploy information from these 
variables and build models that can be useful for predictive purposes as well as accounting for past events [5].

Birth and McVey [6] were among the first scientists to utilize remote sensing techniques to explore new areas of natural resource research. They evaluated the color of grass turf using a ratio of Near Infra-Red (750-nanometer [nm]) to red (650-nm) reflectance, and called it the turf color index. Their work utilized a two-filter instrument called Ratiospect to measure this index on eight samples of turf of three species. The high correlation coefficient (98.4\%) confirmed a strong relationship between the Ratiospect readings and the visual score of turf color. This mathematical relationship gave birth to the development of computer simulations in ecosystems studies.

Several studies have followed Birth and McVey [6] in utilizing satellite remote sensing to overcome natural resource monitoring challenges in terms of space and time. One such study is the need for a better knowledge of the spatial and temporal distribution of surface water resources [7]. Spatially, many sampling programs are limited to few locations, owing to factors such as lack of sufficient financial, institutional, and/or human resources. Hence, the need for a wider coverage of sampling points has been an area of active natural resource remote sensing application [8]-[11]. Similar factors may also impede frequent monitoring programs. Such gaps in sampling periods may pose the risk of missing important incidents, such as flooding, and diminish the robustness of management strategies [8]-[11]. Because of these limitations, researchers have explored new remote sensing tools to understand the mechanism of catchment changes over time.

This work follows from those methodologies in the literature, postulating that Landsat spectral data can enable development of predictive models as early warning systems for impacts of land use changes in the Bumbuna watershed. The objective is to show case the usefulness of Landsat data in providing scientifically proven evidence to pinpoint cause-effect relationships between land-use practices and land cover changes in the study area. To achieve this objective, this work will exemplify a regression algorithm relating water level fluctuations in the reservoir and spectral reflectance values of Landsat 7 Enhanced Thematic Mapper (ETM) and Landsat 8 Optical Land Imager (OLI).

This work will lay the foundation for utilization of Landsat data to solve complex environmental problems in this data scarce region. The results will show case and provide the basis for project management using these approaches. Hence, future actions will not suffer from lack of information in clarifying land cover boundary limits and common interest. In addition, future predictive models from satellite studies will inform management strategies for biodiversity conservation. This is more obvious giving study findings of high species diversity of primates and other large mammals, birds, herptiles, butterflies, bats, and flora [2].

\section{Materials and Methods}

\subsection{Description of Study Area}

\subsubsection{The Bumbuna Watershed}

The Bumbuna watershed drains into Rokel River, one of the major river basins in Sierra 
Leone. The Rokel basin starts in Koinadugu District, in the northeast, and empties into the Atlantic Ocean in the Western Area. Figure 1 shows a Google Earth map of the Rokel basin with the Bumbuna watershed in the upper catchment (circled).

Several communities, companies, and the GoSL depend on Rokel River for various purposes. Communities depend on it for fishing, transport, farming, and domestic use; ADDAX Bio-energy abstracts water from the river for irrigation; London Mining Ltd. utilizes the river to preprocess iron ore; plenty of mining companies depend on it for sand and gold; the BHP, the nation's biggest hydroelectric power supply source, depends on the Bumbuna watershed.

The Bumbuna watershed has a $21 \mathrm{Km}^{2}$ flooded area that drains into a 2,500,000- $\mathrm{m}^{3}$ reservoir, which supports hydroelectric power supply to major cities in the nation [12]. The three affected chiefdoms are Diang and Kansunko chiefdoms in Koinadugu District and Kalasongia chiefdom in Tonkolili District. Figure 2 shows a map of the Bumbuna watershed bounding the Rokel River and the three affected chiefdoms.

\subsubsection{Water Level Determination in the Reservoir}

This study utilized both manual level readings and in situ "Rugged TROLL" absolute pressure data loggers. These loggers respond to changes in water and air pressure and require compensation to remove the effects of air pressure using a separate barometric logger (Rugged BARROW). The rugged troll and rugged barrow, both are easy-to-use software aquatic data logging instruments. The rugged troll measures water temperature and water level while the rugged barrow measures atmospheric pressure. Both instruments have completely sealed bodies that contain non-vented pressure sensor, temperature sensor, real-time clock, microprocessor, lithium battery, and internal memory. The Rugged TROLL 100 hangs by a back-shell hanger from a suspension wire.

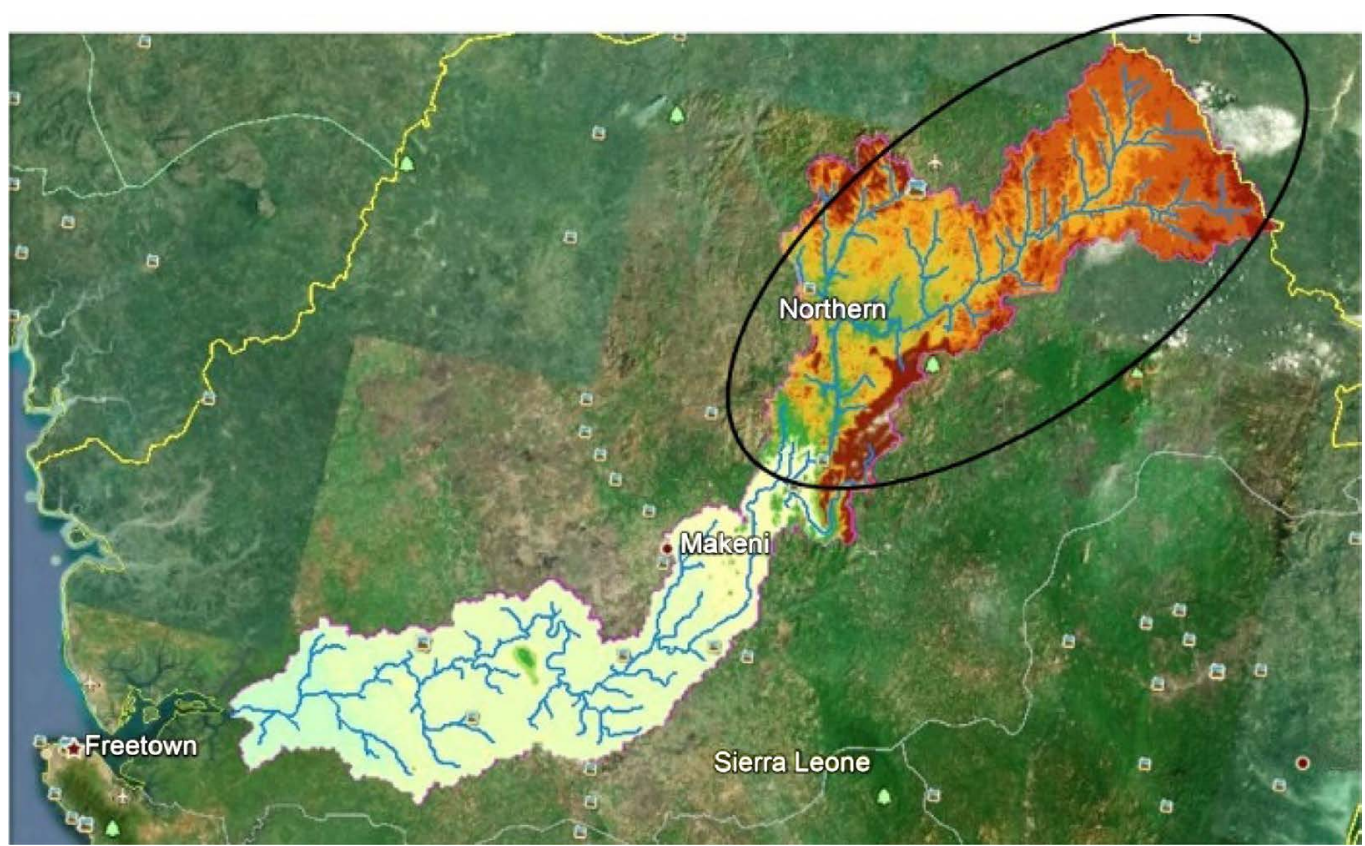

Figure 1. Google earth map showing the Rokel River Basin and the Bumbuna watershed (circled). 


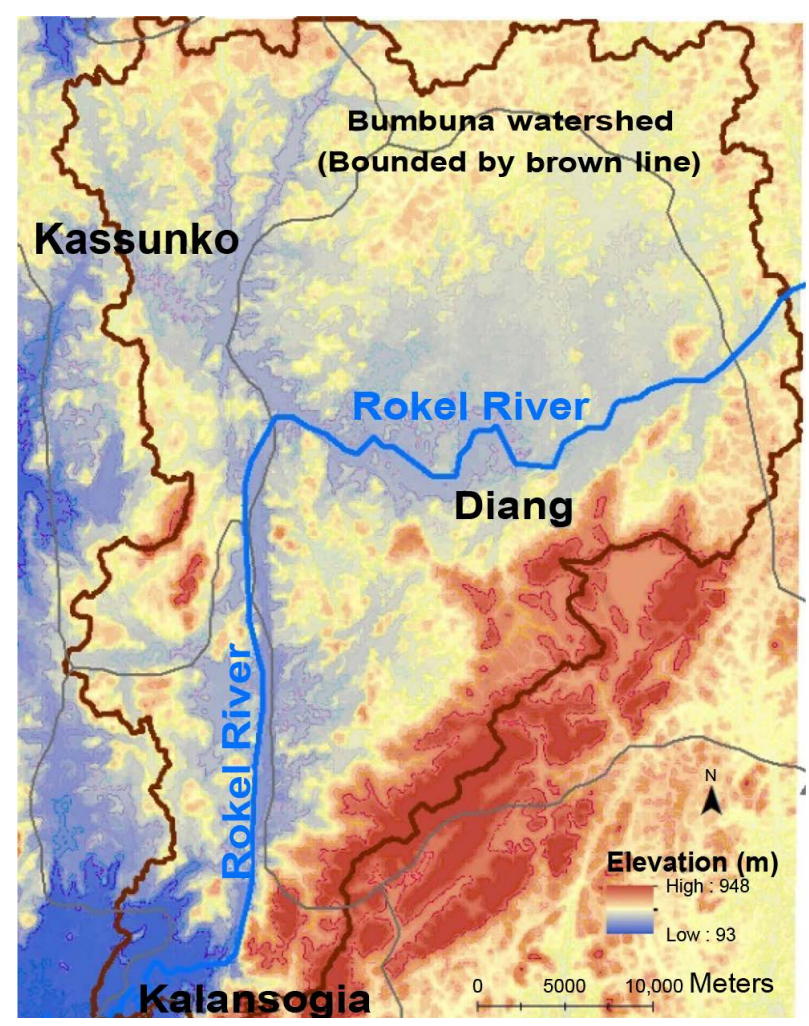

Figure 2. Map of the Bumbuna watershed bounding the Rokel River and the three affected chiefdoms.

Deployment of the instruments followed calibration with manual water levels and customization to take readings at 30-minute intervals. The instrument stored the data in a memory chip installed on the logging device. The Win Situ 5 soft ware utilizes a USB connected docking station to download the data, in CSV file formats, on to a computer.

\subsubsection{Acquisition of Satellite Data}

The United States Geological Survey (USGS) provides Landsat data in tagged image file format (tiff). Using the ESRI Image Classification tool, the mean pixel values (30-m resolution) represented surface reflectance for the overpass dates. The resulting reflectance values informed algorithm development for water level fluctuations over time. The USGS has published, on their web page, band characteristics for Landsat 7 and Landsat 8 [13]. These band characteristics (Table 1) informed inferences from the observed trends.

This research also utilized photographs from digital field cameras. The purpose was to demonstrate visual changes in land cover before and after impoundment of the dam.

\subsubsection{Data Analysis}

Data analysis utilized multiple regression with ANOVA in the Minitab 17 statistical software. All the bands went through stepwise elimination to account for multicollinearity. There was also stepwise elimination of statistically insignificant bands. The null 
hypothesis was that no spectral band could predict water level in the reservoir, on a $95 \%$ confidence interval.

\section{Results and Discussions}

\subsection{Pre-Impoundment and Post-Impoundment Water Levels}

Figure 3 shows two pictures of the Bumbuna dam; the image on the left shows the construction phase of the dam whilst that on the right shows the reservoir in full operations. The water level in the left image shows the original level of the river whilst that on the right shows the current water level in the reservoir.

Figure 4 presents the same information in the form of Landsat images. On the left hand side is a Landsat 7 image acquired on April $9^{\text {th }} 2003$ and that on the right is a Landsat 8 image acquired on February $24^{\text {th }} 2016$. The green color represents vegetations cover derived from the normalized differential vegetation index (NDVI) for this area. The blue line running north-south is the Bumbuna reservoir. These two images represent the same location at the two time periods. They show how land cover in this area has changed over the years.

Calculations using spectral values from the Landsat images show that water level in the river (now reservoir) has increased by 45.5\% from February 2009 to March 2015 while the NDVI, a related indicator [14], has changed by $44 \%$. Thus, Landsat data for this area can be useful in quantifying changes in land cover over time.

Table 1. Useful characteristics of Landsat spectral bands.

\begin{tabular}{cccc}
\hline \multicolumn{2}{c}{ Band number } & Wavelength $(\mathrm{nm})$ & Characteristics \\
\hline Landsat 7 & Landsat 8 & & Blue: bathymetry \\
\hline 1 & 2 & $550-520$ & Green: peak vegetation \\
3 & 3 & $630-690$ & Red: vegetation slopes \\
4 & 4 & $770-900$ & Near Infrared (NIR): biomass content and shorelines
\end{tabular}

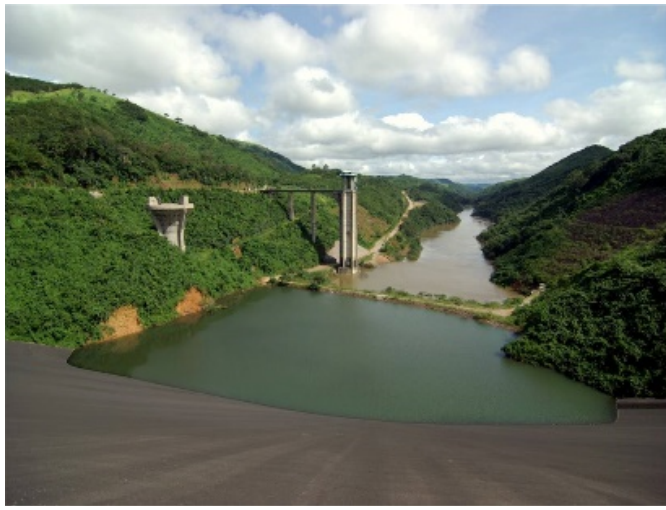

(a)

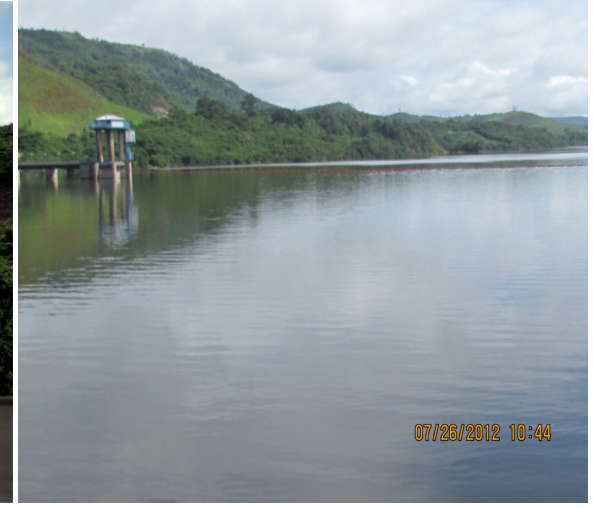

(b)

Figure 3. Images showing construction (a) and operation phases (b) of the Bumbuna reservoir. 
Figure 5 represents water level changes in the reservoir over time. The lowest level in 2009 was $181 \mathrm{~m}$ above sea level (a.s.l); the 2014 low level read at $240 \mathrm{~m}$ a.s.l, a 33\% rise. Figure 5 displays a generally increasing trend of water level over time.

This is a cause for concern giving that the increasing trend become prominent in the rainy season, which is also the farming season. These rural areas, depending primarily on rain-fed agriculture, would need to seek livelihood alternatives if this trend continues [1]. However, early warning systems would help inform BMPs to minimize the likelihood of this problem.

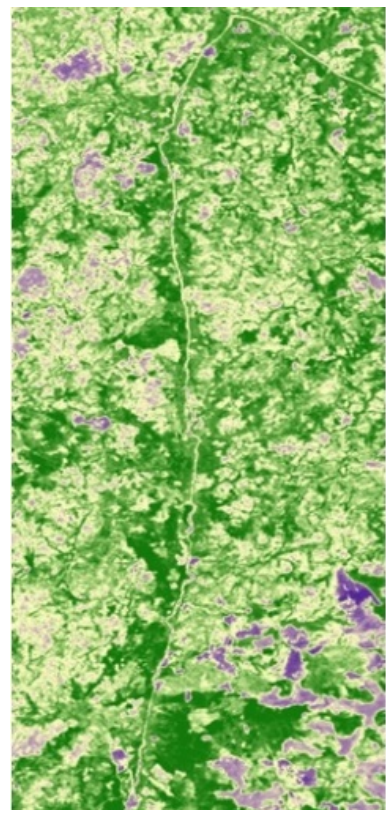

(a)

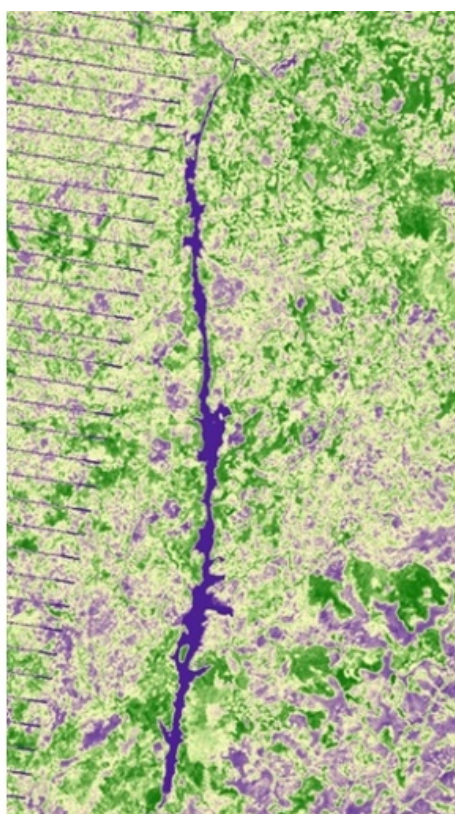

(b)

Figure 4. Landsat images showing pre-impoundment (a) and post-impoundment (b).

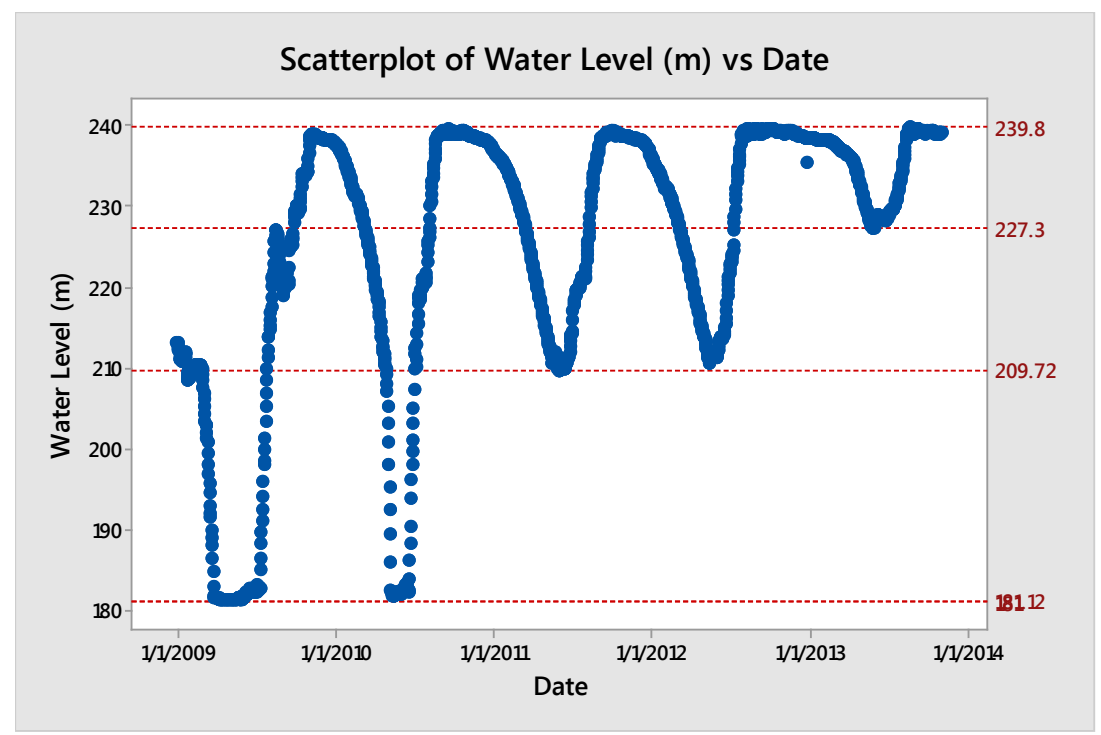

Figure 5. Lowest water level over time since impoundment of the reservoir. 


\subsection{Visual Relationship between Water Level and Spectral Bands}

Figure 6 shows a visual relationship between water level in the reservoir and two Landsat spectral bands. The regression analysis proved Bands 1 and 4 to have statistically significant changes with water level. The gradation in color indicates the range in water level from low to high.

The chart shows a positive linear relationship between water level and band 1, as expected. Depending on the amount of certain substances in a water body, surface reflectance would range in the blue-green-infrared regions of the electromagnetic spectrum. Since water in the reservoir is clear most of the time, the water would reflect high in the blue region [15]. Band 4 has an inverse linear relationship with water level with few exceptions. This trend confirms the fact that NIR differentiates vegetation shoreline from the rest of the water body [13].

\subsection{Simulating the Trends}

Equation (1) shows the regression model for water level in the reservoir. The output of the multiple regression analysis indicates that Band 1 (Blue) and Band 4 (NIR) significantly predict water level in the reservoir. In this case, we rejected the null hypothesis, which states that Landsat spectral values would not predict water level in the reservoir. The $\mathrm{R}^{2}$, which indicates the goodness of fit of the model [16], demonstrates that the model can account for at least $84 \%$ of water level data on a $95 \%$ confidence level (p-value is less than 0.05).

Reservoir Level $(\mathrm{m})=241.74+0.0487$ Band $1(\mathrm{~nm})-0.03534$ Band $4(\mathrm{~nm})$.

Equation (1) Predictive equation for water level in the reservoir.

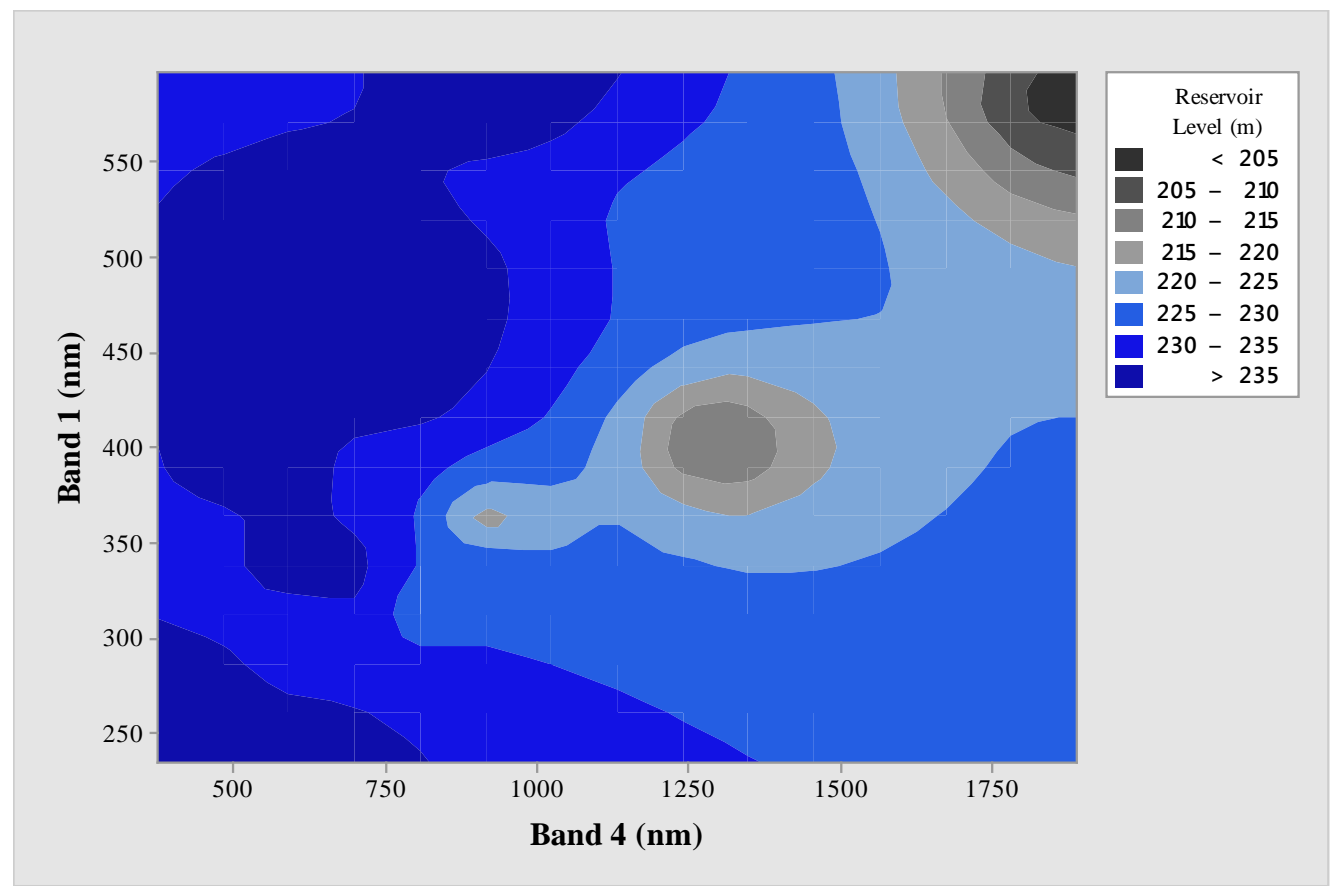

Figure 6. Water level in reservoir and spectral bands. 
Hence, the use of Landsat spectral data can be useful in determining water level in the Bumbuna Watershed. Inputting time factor would enable the development of predictive models for the area. However, since the root mean squared error (4.6) indicates a deviation between the predictive and observed trends, a lower value would make the model more powerful [16]. Generally, studies have shown that similar approaches would enhance prediction of other land cover changes [6].

\section{Conclusions}

The objective of this work was to make a case for the use of Landsat data to predict land cover change in the Bumbuna watershed. Data gathering included both manual and in situ recording of surface water fluctuations in 30-minute intervals, temporally coincident surface reflectance values of Landsat over passing the area, and digital photographs.

The results show a minimum of 33\% water level rise since impoundment in 2009 . Another related land cover change is the NDVI, a 44\% change from 2009. The Landsat data indicated that bathymetry changed by $45.5 \%$ since 2009 . These results strengthened the possibility of quantifying land cover changes using remotely sensed Landsat images.

Results of the regression analysis showed that Band 1 (Blue) and Band 4 (NIR) are better predictors of water level in the reservoir. However, future trials of the regression equation require consideration of the error margin to account for deviations from the observed data. The recommendation is collection of more ground truth data to develop algorithms for predictive models in the watershed. These would serve as early warning systems, informing BMPs for the area.

\section{References}

[1] Schad, I., Schmitter, P., Saint-Macary, C., Neef, A., Lamers, M., Nguyen, L., Hilger, T. and Hoffmann, V. (2012) Why Do People Not Learn from Flood Disasters? Evidence from Vietnam's Northwestern Mountains. Natural Hazards, 62, 221-241. http://dx.doi.org/10.1007/s11069-011-9992-4

[2] BWMA (2008) The Bumbuna Watershed Management Authority and the Bumbuna Conservation Area Act. Freetown.

[3] Barnes, B.B., Hua, C., Holekamp, K.L., Blonski, S. and Spiering, B.A. (2014) Use of Landsat Data to Track Historical Water Quality Changes in Florida Keys Marine Environments. Remote Sensing of Environment, 140, 485-496. http://dx.doi.org/10.1016/j.rse.2013.09.020

[4] Campbell, J.B. and Wynne, R.H. (2011) Introduction to Remote Sensing. 5th Edition, The Guilford Press, New York.

[5] Pettorelli, N., Laurance, W.F., O’Brien, T.G., Wegmann, M., Nagendra, H. and Turner, W. (2014) Satellite Remote Sensing for Applied Ecologists: Opportunities and Challenges. Applied Ecology, 51, 839-848. http://dx.doi.org/10.1111/1365-2664.12261

[6] Birth, G.S. and McVey, G.R. (1968) Measuring the Color of Growing Turf with a Reflectance Spectrophotometer. American Society of Agronomy, 60, 640-643.

[7] Pekel, J.F., Vancutsem, C., Bastin, L., Clerici, M., Vanbogaoert, E., Bartholome, E. and Defourny, P. (2014) A near Real-Time Water Surface Detection Method Based on HSV 
Transformation of MODIS Multi-Spectral Time Series Data. Remote Sensing of Environment, 140, 704-716. http://dx.doi.org/10.1016/j.rse.2013.10.008

[8] Novoa, S., Chust, G., Sagarminaga, Y., Revilla, M., Borja, A. and Franco, J. (2012) Water Quality Assessment Using Satellite-Derived Chlorophyll-A within the European directives, in the southeastern Bay of Biscay. Marine Pollution Bulletin, 65, 739-750.

http://dx.doi.org/10.1016/j.marpolbul.2012.01.020

[9] Kavurmac1, M., Ekercin, S., Altaş, L. and Kurmaç, Y. (2013) Use of EO-1 Advanced Land Imager (ALI) Multispectral Image Data and Real-Time Field Sampling for Water Quality Mapping in the Hirfanl Dam Lake, Turkey. Environmental Science and Pollution Research, 20, 5416-5424. http://dx.doi.org/10.1007/s11356-013-1553-9

[10] Villar, R.E., Martinez, J.-M., Guyot, J.-L., Fraizy, P., Armijos, E., Crave, A., Bazán, H., Vauchel, P. and Lavado, W. (2012) The Integration of Field Measurements and Satellite Observations to Determine River Solid Loads in Poorly Monitored Basins. Journal of Hydrology, 444-445, 221-228. http://dx.doi.org/10.1016/j.jhydrol.2012.04.024

[11] Villar, R.E., Martinez, J.-M., Le Texier, M., Guyot, J.-L., Fraizy, P., Meneses, P.R. and de Oliveira, E. (2013) A Study of Sediment Transport in the Madeira River, Brazil, Using MODIS Remote-Sensing Images. Journal of South American Earth Sciences, 44, 45-54. http://dx.doi.org/10.1016/j.jsames.2012.11.006

[12] BHP (2016) Bumbuna Hydroelectric Project Policy Brief. Bumbuna Watershed Management Authority, Bumbuna.

[13] USGS (2016) Unitesd States Geological Surveys. http://landsat.usgs.gov

[14] Zhou, Y., Wenninger, J., Yang, Z., Yin, L., Huang, J., Hou L., Wang, X., Zhang, D. and Uhlenbrook, S. (2013) Groundwater-Surface Water Interactions, Vegetation Dependencies and Implications for Water Resources Management in the Semi-Arid Hailiutu River Catchment, China-A Synthesis. Hydrology and Earth System Sciences, 17, 2435-2447. http://dx.doi.org/10.5194/hess-17-2435-2013

[15] Moore, T.S., Dowell, M.D., Bradt, S. and Verdu, A.R. (2014) An Optical Water Type Framework for Selecting and Blending Retrievals from Bio-Optical Algorithms in Lakes and Coastal Waters. Remote Sensing of Environment, 143, 97-111. http://dx.doi.org/10.1016/j.rse.2013.11.021

[16] Karen (2016) Assessing the Fit of Regression Models. http://www.theanalysisfactor.com/assessing-the-fit-of-regression-models/

\section{Submit or recommend next manuscript to SCIRP and we will provide best service for you:}

Accepting pre-submission inquiries through Email, Facebook, LinkedIn, Twitter, etc. A wide selection of journals (inclusive of 9 subjects, more than 200 journals)

Providing 24-hour high-quality service

User-friendly online submission system

Fair and swift peer-review system

Efficient typesetting and proofreading procedure

Display of the result of downloads and visits, as well as the number of cited articles Maximum dissemination of your research work

Submit your manuscript at: http://papersubmission.scirp.org/ 